УДК 35.08:17.023 (4)

DOI https://doi.org/10.32836/2310-9653-2020-3.3

В. В. Пержун, кандидат соціологічних наук, доцент, докторант кафедри суспільного розвитку та суспільно-владних відносин Національної академії державного управління при Президентові України

\title{
СОЦІАЛЬНО-ІСТОРИЧНІ ДЖЕРЕЛА ФОРМУВАННЯ УПРАВЛІНСЬКОЇ КУЛЬТУРИ В УКРАЇНІ ДАВНІХ ЧАСІВ
}

Нині в Украӥні продовжуються трансформаиійні прочеси майже в усіх галузях життя суспільства й держави. Певним чином вони проходять і у сфері публічного управління. Складовою частиною публічного управління є управлінська культура, яка виступає окоміром управлінської діяльності управлінців різних рівнів - від ичентральних органів влади до службовців місцевого самоврядування. Зрозуміти й осмислити ці проблеми неможливо без звернення до джерел управління та управлінськоі культури, які започаткувалися на території сучасної України з давніх-давен.

Стаття присвячена питанням зародження початкових елементів управлінської культури в Украӥні, з держави Антів та аж до початку феодальної роздробленості Київської Русі, а також діяльності Данила Галицького як твория та фундатора Галицько-Волинської держави.

Уже тоді, як свідчать сочіально-історичні джерела, про які буде йтися в публікачї, починають формуватися певні якості управлінської культури - чесність, справедливість, любов до рідної землі, навчання та досвід, колективізм управління, авторитет князя тощчо. Усі иүі якості управлінської культури актуальні й зараз, особливо для сучасної української управлінської еліти, оскільки в переважній більшості з них вони, на превеликий жаль, відсутні.

Усвідомлення важливості дослідження джерел та етапів формування та становлення управлінської культури в Україні - ие, так би мовити, взаємозв'язок соиіальних поколінь, иілісність триєдиного суспільного феномену «минуле сучасне - майбутнє», коли історична пам'ять не дозволяє нації забувати про свою иінність і свойх пращурів, які були в джерелах творення української держави, управлінських досягнень, перемог і невдач. На уроках і помилках минулого потрібно вчитися та не повторювати їх зараз.

Ключові слова: управлінська культура, управлінська діяльність, держава, джерела, формування, влада, князь, віче.

\section{V. Perzhun. Socio-historical sources of formation of management culture in Ukraine of ancient times}

Today in Ukraine transformation processes continue in almost all spheres of life of society and the state. In a way, they take place in the field of public administration. A component of public administration is the management culture, which acts as a measure of the management activities of managers at various levels - from central government to local government officials. It is impossible to understand and comprehend these problems without referring to the origins of management and managerial culture, which began on the territory of modern Ukraine from ancient times.

This article is devoted to the origin of the initial elements of administrative culture in Ukraine, from the state of Ants to the beginning of the feudal fragmentation of Kievan Rus, as well as the activities of Danylo Halytsky as the creator and founder of the Halych-Volyn state.

Even then, as evidenced by socio-historical sources, which will be discussed in the publication, begin to form certain qualities of management culture - honesty, justice, love for their homeland, training and experience, collectivism management, the authority of the prince and more. All these qualities of managerial culture are relevant even now, especially for the modern Ukrainian management elite, because in the vast majority of them they are, unfortunately, absent.

Awareness of the importance of researching the sources and stages of formation and formation of management culture in Ukraine is, so to speak, the relationship of social generations, the integrity of the triune social phenomenon "past-present-future", when historical memory does not allow the nation to forget its value and their ancestors, who were at the origins of the Ukrainian state, managerial achievements, victories and failures. You need to learn from the lessons and mistakes of the past and not repeat them now.

Key words: managerial culture, managerial activity, state, sources, formation, power, prince, chamber.

Постановка проблеми. Науково-теоретичні питання зародження та формування управлінської культури в Україні потребують подальшого вивчення, оскільки вони донедавна майже не досліджувалися, а саме поняття «управлінська культура» 3'явилося в наукових дискусіях зовсім недавно. Більше писали про організаційну культуру, політичну культуру, економічну культуру, національну культуру, масову культуру й так далі. Нині ж, в умовах управлінської нестабільності, постає нагальна проблема теоретичного дослідження та практичного застосування принципів, ознак та якостей управлінської культури в управлінській діяльності, що почали зароджуватися на теренах України в глибоку давнину.

Аналіз останніх досліджень і публікацій. Наразі необхідно зауважити, що фундаментальних досліджень iз проблематики формування управлінської культури як соціально-політичного й державно-управлінського 
феномену суспільства в Україні дотепер немає. Окремі положення та ідеї про управлінську культуру в Україні висували відомі вчені й громадсько-політичні діячі недалекого історичного минулого: М. Грушевський («Про старі часи на Україні»), Д. Донцов («Дух нашої давнини»), В. Липинський («Листи до Братів-Хліборобів), І. Крип’якевич («Галицько-Волинське князівство»), С. Рудницький («Україна з політично-географічного становища») й інші.

Серед сучасних українських вчених-істориків варто назвати М. Брайчевського («Про українську державність»), Л. Залізняка («Стародавня історія України»), А. Смолія («Україна. Поступ історії»), Н. Яковенко («Нарис історії середньовічної та ранньомодерної України»), С. Кульчицького («Київ стародавній і сучасний») та інших.

Досліджують деякі моменти управлінської культури й представники управлінської науки в Україні: О. Петроє («Еволюція моделі державного управління»), В. Бакуменко («Державне управління: основи теорії, історія і практика»), Н. Нижник і Л. Пашко («Управлінська культура: теоретичне поняття чи управлінська поведінка»), В. Козюра та Ю. Ящуринський («Еволюція управлінської думки»), В. Пержун («Історичні витоки формування управлінської культури») й інші.

Мета статті - проаналізувати доступні нам джерела, де говориться про творення української державності, початкові етапи управління нею, а також які якості управлінської культури були притаманні в Україні для того соціально-історичного періоду.

Виклад основного матеріалу. Перші деякі ознаки та якості управлінської культури на території сучасної України почали формуватися в період зародження та утвердження держави Антів. Її територія охоплювала Подніпров'я, Подністров'я та Побужжя. Проіснувала вона понад 200 років. Саме тоді відбулося об'єднання в державний союз племен, що проживали на цій землі. М. Грушевський вбачав у антах складову частину процесу етногенезу українського народу й наголошував, що вони є «першим періодом життя українського народу» [2, с 27].

Відомий український історик М. Брайчевський писав, що анти - це «крайні» племена, тобто люди, які «жили на краю». Звідси він робить висновок про саме походження назви Україна й українці [1, с. 78-80].

Суспільно-політичний устрій держави Антів нагадував собою ранні європейські держави, але з однією відмінністю - влада й управління тут належали не одній людині, а народному зібранню. Внутрішні й зовнішні питання народне зібрання розв'язувало колективно й у переважній більшості узгоджено. Про це писав візантійський історик Прокопій Кесарійський [5, с. 117]. Коли ж починалися військові походи, анти обирали головного воєначальника (князя), який починав виконувати управлінські функції. Форма правління була перехідною - від докласової до класової. Більшість дослідників називають таке управління військовою демократією.

До характерних рис управлінської діяльності й певної управлінської культури антів можна віднести: почуття поваги й любові до рідної землі, чесність і справедливість щодо своїх земляків, розуміння важливості єдності людини й природи, колективізм у прийнятті державних і суспільних рішень, визнання лідерства у військовій справі тощо.

Важливою та водночас суперечливою віхою формування української державності, певної управлінської діяльності наших предків, їхньої управлінської культури є таке письмове джерело, як «Велесова Книга». Єдиної думки щодо походження цього джерела немає. Одні науковці (Б. Рибаков, Н. Данилевський, В. Соболєв, Г. Грабович, Г. Півторак, П. Толочко й інші) вважають їі підробкою ХІХ століття; інші (Ю. Бєгунов, Р. Пешич, Р. Міроєвич, Б. Яценко, О. Білодід, С. Наливайко тощо) наполягають, що це дійсно історичне джерело дохристиянської Русі. Ми не будемо розглядати ці погляди й суперечки, оскільки їх мають розв'язати фахівці - історики, філологи, лінгвісти, філософи, культурологи й так далі.

Хочемо зупинитися на тих важливих для нас моментах, де можна віднайти ознаки та якості управлінської діяльності й управлінської культури наших давніх пращурів. Переважно «Велесова Книга» присвячена проблемам світорозуміння та світогляду, вона демонструє нам етнічні джерела й походження українського народу.

Досліджуючи таблички «Велесової Книги», можна віднайти в ній факти, що в ті давні часи на території сучасної України проявлялося деяким чином демократичне правління у формі виборів князів та інших представників управлінської влади. Ось що ми читаємо: «У ті часи, після Кия, князями обирали багатьох отців, а князі окремі й всякі після князювання ставали на вічі простими мужами. І так ставала земля розквітлою, і вибрані князі дбали про людей і хляби, одержували і їжу, і всякий пожиток од людей своїх» [7, с. 44.]. I як продовження: «Се бо князів наших вибирали, аби влада їхня про нас піклувалася» [7, с. 44]. Отже, можна вважати, покладаючись на ці слова, що наші предки були знайомі й використовували в практичній управлінській роботі початкові основи демократії, а саме - головним господарем був народ (Віче), яке обирало, чи краще наймало на роботу управлінського характеру князя, тобто управлінськими функціями займалися підготовлені, чесні й справедливі люди, яких за їхні якості й обирали до влади. Усі важливі управлінські справи розв’язувало Віче, воно ж виконувало функцію контролю за виконавчою (сучасною мовою) владою, давало оцінку їхньої роботи, приймало рішення про винагороду чи покарання, підвищувало чи понижувало їхній управлінський статус і так далі. А найважливішими цінностями управлінської діяльності були якості управлінської культури: свобода, честь і справедливість. Хоча тут також важливо зауважити, що не всі науковці й не тільки погоджуються на таке розуміння змісту «Велесової Книги».

Значним етапом формування управлінської культури є історичний період творення, становлення та розвитку держави Київська Русь. Відомий науковець, дослідник стародавньої історії України Л. Залізняк пише: «Українські 
історики, починаючи з автора «Історії Русів» кінця XVIII століття, вважають, що Київську Русь як державу консолідував проукраїнський етнос» [3, с. 126]. Таку ж позицію творення української державності підтверджують визнані постаті історичної науки: М. Грушевський («Анти»), І. Крип’якевич («Процес творення суспільної організації в українській історії»), С. Рудницький («Чому ми хочемо самостійної України»), М. Брайчевський («Конспект історії України»), Я. Дашкевич («Перегук віків: три погляди на минуле і сучасне України»), Н. Полонська-Василенко («Історія України»), Г. Півторак («Українці. Звідки ми і наша мова»), О. Сфименко («Історія українського народу»), Ю. Шевельов («Чому общерусский язик, а не вібчоруська мова»), А. Смолій та О. Гуржій («Як і коли почала формуватися українська нація») та інші.

Серед джерел управлінської думки часів Київської Русі насамперед варто згадати «Руську Правду», яка складається з «Правди Ярослава», «Правди Ярославичів» і «Статуту Володимира Мономаха». «Руська Правда» $є$ збірником законів не тільки джерелом пізнання історичних, господарських, правових, майнових, соціальних, економічних аспектів розвитку Київської Русі, але й структурних, організаційних, управлінських змін, що відбувалися в тодішньому суспільстві й державі.

Перше, що хотілося б відзначити, - це спробу авторів через «Руську Правду» як юридичний закон систематизувати державні органи влади, де управлінська діяльність базувалася б на законі з якостями управлінської культури, а саме: управлінські знання та досвід, справедливість розв'язання проблем управлінцями, колективність управлінської діяльності (Боярська Рада, Віче як народне зібрання), професіоналізм (управлінський, правовий, військовий, фінансовий, господарський тощо), авторитет князя як у внутрішній, так і у зовнішній політиці й тому подібне. Друге - «Руська Правда» визначає, що за формою державного правління Київська Русь була ранньофеодальною монархією; за державною формою устрою - федерацією (федерація зібраних земель); за політичним режимом - автократією. Водночас необхідно зауважити, що вища законодавча, судова, військова й адміністративна влада знаходилася в руках великого князя київського, який спирався на своє військо - княжу дружину. І останнє, що має відношення до управління та управлінської культури. Окрім князя, певну обмежену владу мала Боярська Рада, водночас бояри мали вплив на князя. Органом місцевого самоврядування було народне Віче - збори жителів населеного пункту. Вони розв'язували найважливіші місцеві проблеми й виконували деякі законодавчі функції. Віче також впливало на управління князя, навіть мало змогу його звільнити, проте не могло самостійно пропонувати або приймати державні закони. Дещо пізніше, коли розпочалася роздробленість Русі, утвердився так званий «колективний сюзеренітет», де нагальні важливі державні справи розв'язували колективні збори найвпливовіших князів на князівських з’їздах: Вишгородському 1072 року, Городецькому 1026 року, Любецькому 1097 року, Уветицькому 1100 року й інших.

Отже, Руська Правда - це закон, в якому регулювалися правові, соціальні, економічні, майнові, управлінські тощо відносини. На той період історичного часу вона носила досить демократичний характер, оскільки розмежовувалися гілки влади, управління мало характер і централізованого, й місцевого, певним чином владою гарантувався захист вільним людям тощо.

Важливим історико-політичним та управлінським джерелом є «Повість минулих літ» Нестора-літописця. До таких історичних джерел також потрібно ставитися критично й вивчати виважено. Щодо цього один із найвідоміших дослідників Київської Русі О. Шахматов писав: «Рукою літописця керував у більшості випадків не високий ідеал далекого від життя та мирської суєти благочестивого пустельника, який вміє дати правдиву оцінку подіям, що розгортаються довкола нього, й особами, що керують цими подіями <... рукою літописця керували політичні пристрасті й мирські інтереси» [6, с. 200]. Ми не можемо вважати цей твір (як і «Велесову Книгу») досить об’єктивним і документальним, але його необхідно досліджувати, оскільки в кожної нації є свої такі ж писемні джерела, де не все історично доведено. А проте, вони ніби морально підтримують і вселяють надію в майбутнє, позаяк у соціально-історичній пам'яті будь-якого народу мають бути величне історичне минуле, дієва історична пам'ять і взаємозв'язок поколінь.

Переважно «Повість минулих літ» присвячена князівському правлінню, військовим походам, боротьбі Русі з кочовими племенами, а також у ній вперше з'являється гіпотеза про норманську теорію походження Київської держави, з якою ми не погоджуємося. Окрім цього, в літописі багато легенд і міфів, в яких возвеличують князів, їхні військову мудрість і знання, княже військо, а подекуди й простих людей, які вірно служили й боронили свою землю.

Ще одним джерелом, з якого можна черпати джерела управлінської діяльності й управлінської культури України періоду Київської Русі, є «Повчання» дітям» Володимира Мономаха. Переважна більшість дослідників вбачають у «Повчанні» певний доробок педагогічної науки й виховного процесу. Така позиція вірна, але такий твір - це також шляховик державницьких традицій та ідей самого Володимира Мономаха, який намагався передати їх своїм наступникам. Ба більше, можна говорити про державно-управлінський доробок, свого роду настанови щодо внутрішньої та зовнішньої політики держави. Основними ознаками управлінської культури в «Повчанні» є: любов до Батьківщини, толерантність у розв'язанні соціальних суперечностей, збереження миру, патріотизм, роль і значення князівського правління, здорове виховання молоді, працелюбство, честь і гідність людини, уміння 
господарювати тощо. Підтверджуючи ці слова, наведемо цитату одного з українських дослідників такого періоду: «У «Повчанні» Мономах розробив широку низку правил і норми поведінки, які вважав критерієм вихованості молодої людини. Не останнє місце в цьому творі належить і питанням патріотичного й громадянського виховання молоді. Володимир Мономах вперше обгрунтував необхідність переходу від релігійно-аскетичного виховання до практичних завдань, пов'язаних із повсякденним життям» [4, с. 144].

Визначним твором періоду феодальної роздробленості Київської Русі $є$ «Слово о полку Ігоревім». У ньому прослідковуються деякі якості й ознаки управлінської культури. Найперше - загальнодержавний інтерес має бути вищим за особистий. Далі автор наголошує на колективізмі й згуртованості перед зовнішніми викликами, а саме перед монголо-татарською навалою на Русь. Внутрішні чвари й незгоди, боротьба за владу між князями, послаблення ролі й значення народних зборів (Віче), роз'єднаність військових сил - все це призведе до важких наслідків для держави. Тільки політичне й військове об'єднання, згуртованість, консолідація, колективні управлінські рішення можуть привести до успішного захисту своєї землі й здорових устремлінь у житті громадян. Такі настанови актуальні й нині для нашої управлінської еліти й влади, всього громадянського суспільства, особливо в умовах війни на Донбасі й агресивних дій із боку Російської Федерації.

Таким чином, управлінська культура Київської Русі переважно характеризується централізованою владою на чолі з князем. Разом із тим, певне місце в управлінні займали Боярська Рада й народне Віче, котрі впливали на політичне життя держави й управлінську діяльність князя, але з часом вони втрачали свою владну дієвість. Значну роль у формуванні управлінської культури також відігравала церква й релігія, які на той період були ініціаторами й організаторами майже всієї освіти й школи. Позитивну роль відігравала також світська література й світські вчителі, які свої знання та досвід передавали учням, котрі з часом ставали управлінцями різних рангів.

Окремою складовою частиною творення української держави є Галицько-Волинське князівство (держава), яка успішно протистояла в боротьбі з монголо-татарською навалою. Дослідники цього періоду вважають це заслугою Данила Галицького, який себе проявив хорошим дипломатом, вмілим управлінцем, досвідченим господарником і фаховим воєначальником. Його індивідуальні чесноти, державницький досвід та управлінські вміння описує літописець: «Був бо він сміливий і хоробрий - від «стопи ноги його й аж до верху голови його не було в ньому вади» < .. > Сей же король Данило [був] князем добрим, хоробрим і мудрим, який спорудив городи многі, і церкви поставив, і оздобив їх різноманітними прикрасами, і братолюбством він світився був із братом своїм Васильком. Сей же Данило був другий по Соломонові» [8, с. 103]. У цих словах можна віднайти риси управлінської культури Данила Галицького, й напевно також його оточення: мудрість, відвага, військовий і дипломатичний хист, щедрість, естетичний зовнішній вигляд, моральність, повага до своїх підданих, внесок у розвиток культури й освіти тощо. Але найголовнішим досягненням князя Данила та його управлінців було, безумовно, те, що вони зуміли позбутися внутрішніх чвар і встановити мир у своїй державі й налагодити взаємовигідні, рівноправні відносини із сусідніми державами.

Висновки і перспективи подальших досліджень. Управлінська культура вбирає в себе знання, професійні навички, досвід попередньої діяльності, моральні якості, етичні переконання та естетичні вподобання, вміння вести діалог і слухати, колективізм у роботі, застосування нових технологій тощо. Все це необхідно шукати в нашому соціально-історичному минулому, коли зароджувалися, формувалися та утверджувалися позитивні якості управлінської культури. Звичайно, на творчий потенціал та успішний розвиток української державності впливали як внутрішні, так і зовнішні фактори, й не завжди позитивні й конструктивні. Те, що Україна як держава довгий час перебувала в складі інших державних утворень, мало переважно негативний характер і також впливало на фактори формування управлінської думки й управлінської діяльності на практиці. А проте, ми вважаємо, що в нас $є$ всі передумови до успішного впровадження позитивних управлінських ідей у живе практичне управління суспільством і державою. А базисним фундаментом такого впровадження можуть слугувати досягнення управлінської культури минулого, які нині стають актуальними й важливими.

Перспективою подальших досліджень у цьому напрямі є вивчення основних ознак, принципів та якостей управлінської культури в Україні періоду визвольних змагань українського народу, внесок у світову управлінську думку наших вчених-теоретиків XIX-XX століття, а також новітні досягнення управлінської науки в сучасній Україні.

\section{Список використаних джерел:}

1. Брайчевський М.Ю. Про українську державність. Нью-Йорк - Торонто - Мюнхен, 1989. Т. XXVI. ч. 4. С. 76-81.

2. Грушевський М. С.Про старі часи на Україні : Коротка історія України. Київ : АТ «Оберіги», 1991.104 с.

3. Залізняк Л.Л. Від склавинів до української нації. Київ : Вид-во «Бібліотека українця», 2004. 253 с.

4. Іванов М.С. Політико-дидактичні парадигми часів Київської Русі (X-XIII ст.). Наукові записки : збірник статей. Київ : ІПіЕНД, 2003. Вип. 24. С. 137-145.

5. Курбатов Г.Л. Ранневизантийские портреты : К истории общественно-политической мысли. Ленинград : Изд-во ЛГУ, 1991. 272 с. 
6. Стрілець О.Г. Дослідження «Повісті минулих літ» у працях О.О. Шахматова. Збірник наукових праиุь Харк. нац. пед. ун-ту ім. Г.С. Сковороди. Серія «Історія та географія». 2010. Вип. 38. С. 200-202.

7. Шпоть О.С. «Велесова Книга» як інструмент з історії демократії. Київ : ПП «Коронатор», 2006.62 с.

8. Яковенко Н.М. Нарис історії середньовічної та ранньомодерної України. Київ : Критика, 2009. 582 с.

\section{References:}

1. Braichevskyi M. Yu. Pro ukrainsku derzhavnist. Niu-York-Toronto-Miunkhen, 1989. T. KhKhVI. Ch. 4. S. 76-81.

2. Hrushevskyi M. S. Pro stari chasy na Ukraini: Korotka istoriia Ukrainy. Kyiv: AT «Oberihy», 1991. 104 s.

3. Zalizniak L. Vid sklavyniv do ukrainskoi natsii. Kyiv: Vyd-vo «Biblioteka ukraintsia», 2004. 253 s.

4. Ivanov M. Polityko-dydaktychni paradyhmy chasiv Kyivskoi Rusi (Kh-KhIII st.). Naukovi zapysky. Zbirnyk statei. Kyiv: IPiEND, 2003. Vyp. 24. S. 137-145.

5. Kurbatov H. L. Rannevyzantyiskye portreti: K ystoryy obshchestvenno-polytycheskoi mysly. Lenynhrad: Yzd-vo LHU, 1991. $272 \mathrm{~s}$.

6. Strilets O. H. Doslidzhennia «Povisti mynulykh lit» u pratsiakh O. O. Shakhmatova. Zbirnyk naukovykh prats Khark. nats. ped. un-tu im. H. S. Skovorody. Ser. «Istoriia ta heohrafiia». 2010. Vyp. 38. S. 200-202.

7. Shpot O. S. «Velesova Knyha» yak instrument z istorii demokratii. Kyiv: PP «Koronator», 2006.62 s.

8. Iakovenko N. M. Narys istorii serednovichnoi ta rannomodernoi Ukrainy. Kyiv: Krytyka, 2009. 582 s. 